\title{
Stabilisation of Olive Oil of the Arbequina Variety During Storage Time by Enrichment with
} Extracts of Olive Stones of the Picholine Variety

\section{Mohamed Hazzab ${ }^{1}$, Aziz Hasib ${ }^{* 1}$, Abdelali Boulli ${ }^{2}$, Abdelkarim Khiraoui ${ }^{1,2}$, Reda Elkacmi ${ }^{1}$, Otmane Boudouch ${ }^{1}$, Mustapha Bouzaid ${ }^{1}$}

1. Environmental and Agro-Industrial Process Team, Faculty of Sciences and Technology, University of Sultan Moulay Slimane, BP 523, Beni-Mellal, Morocco.

2. Ecology and Biodiversity Team, Faculty of Sciences and Technology, University of Sultan Moulay Slimane, BP 523, BeniMellal, Morocco.

*Corresponding author's E-mail: azhasib@yahoo.fr

Received: 24-02-2021; Revised: 17-04-2021; Accepted: 26-04-2021; Published on: 15-05-2021.

\section{ABSTRACT}

Two samples of olive oils of the Arbequina variety were enriched with different extracts of olive stones of Moroccan Picholine variety, the olive stones used are generated in the process table olive preparation and olive oil extraction industry. The enriched oils were analyzed in order to evaluate the influence of the enrichment on of their quality during storage time. The following parameters were determined: acidity, peroxide values, absorption coefficients K270 and K232 for nine months of storage in the dark at room temperature. The prepared extracts of olive stones were characterized in terms of phenolic content and antiradical activity by spectroscopic methods. The results of our study show that the oil of the Arbequina variety is less stable in terms of oxidation compared to the oils of the Moroccan variety Picholine. Enrichment with olive kernel extracts partially reduced acid hydrolysis and increased resistance to oxidation especially in oils enriched with seedless olive kernel extracts. The lowest peroxide value, after nine months, was observed in oil enriched with extracts of seedless olive stone (E1: $13.31 \pm 0.25 \mathrm{Meq}(\mathrm{O} 2) / \mathrm{kg}$, E2: $14.52 \pm 0.19 \mathrm{Meq}(\mathrm{O} 2)$ / kg) compared to the Arbequina oil control sample (E1: $17.68 \pm 0.23 \mathrm{Meq}(\mathrm{O} 2) / \mathrm{kg}$ and E2: $20.16 \pm 0.17 \mathrm{Meq}(\mathrm{O} 2) / \mathrm{kg})$ and to Picholine oil (E1: $12.54 \pm 0.24 \mathrm{Meq}(\mathrm{O} 2) / \mathrm{kg}$, and E2: $12.82 \pm 017 \mathrm{Meq}(\mathrm{O} 2) / \mathrm{kg}$ ). These results are confirmed by measuring the coefficients K232 and K270. The results show that stone extracts can extend the storage times of olive oil and also have excellent antioxidant activity.

Keywords: Oils oxidation, phenolic compounds; antioxidant activity; natural antioxidants, olive by-products, storage time.

QUICK RESPONSE CODE $\rightarrow$

DOI:

10.47583/ijpsrr.2021.v68i01.038

DOI link: http://dx.doi.org/10.47583/iipsrr.2021.v68i01.038

\section{INTRODUCTION}

T he phenomenon of lipid oxidation in virgin olive oil is a major preoccupation for the olive oil industry and the consumer because it causes changes in the organoleptic quality of the food such as flavor and appearance, but also a significant loss of the nutritional value of the food due to the formation of carbonyl compounds and hydroperoxides ${ }^{1}$.

In Morocco, the olive oil sector plays a very important role in economy with a national production of 700000 tons of olive oil ${ }^{2}$. The International Olive Council (IOC 2013) defines four commercial graded categories of olive oil based on their acidity such as extra virgin, virgin, ordinary virgin, and oil lampant. A combination of factors influences the quality of olive oil such as variety, method of harvesting, extraction process, and storage conditions ${ }^{3,4}$.
It has long been known that the chemical composition of virgin olive oil is affected by genetics (cultivar) and environmental factors (dietary characteristics and climatic conditions). Therefore, the production area of olive oil largely determines the special characteristics of olive oil. In the past few years, people have become more and more interested in the geographic classification of virgin olive oil, which is a reliable certification and quality standard that can be used as a food with identified growth areas. Many studies have been carried out to determine the initial components from different geographical origins based on different chemical parameters such as FA composition, hydrocarbon composition, terpenes, pigment composition, and phenol composition. Press olive oil for characterization $^{5}$.

The dominant varieties of olives in Morocco are the Moroccan Picholine, Haouzia, Menara and Arbequina (Spanish variety). In recent studies, the Spanish variety (Arbequina) recently appreciated by many producers due to its high olive oil yield per hectare ${ }^{6}$. Arbequina is one of the main olive varieties in Spain. It is widely known in the international oil market for its excellent taste and flavor. The name of this variety is due to the municipality of Arbeca (Lleida, Catalonia, Spain) where it was first grown. Its characteristics are strong resistance, low vigor, small 
fruit and high productivity ${ }^{5}$. Moreover, their oil still remains unstable, due to its low content of natural antioxidants compared to Moroccan varieties ${ }^{6}$. In addition, the study of the oxidative stability of olive oil at $60^{\circ} \mathrm{C}$ shows that Arbequina oil is more prone to oxidation and loses its designation as extra virgin olive oil after a few weeks of storage, but the variety Picholine has a high stability ${ }^{7}$.

In order to solve the stability problems of oils and other foods containing a fraction of oil, butter or fat, producers often use synthetic antioxidants such as butylated hydroxyanisole (BHA), butyl hydroxytoluene (BHT), terbutylhydroquinone (TBHQ). However, consumers do not accept synthetic products in their foods because these food additives pose many health risks, including allergies, cancer and carcinogenesis ${ }^{8}$.

The phenolic compounds are the secondary metabolites of plants, which play an important role in disease resistance ${ }^{9}$, 10. In general, the interest of these compounds is related to their antioxidant activity and the promotion of their health benefits ${ }^{11}$. The Studies show that the phenolic compounds in olive oil are powerful antioxidants, both in vivo and in vitro ${ }^{12}$. In addition, phenolic extracts obtained from olive trees (fruits, leaves and pomace) have been reported to have high antioxidant activity ${ }^{13}$.

The main polyphenol in green olives is the oleuropein, its concentration decreases during olives maturation ${ }^{14}$, in parallel with the oleuropein decrease, there is an increase of hydroxytyrosol glucoside, and consequently this polyphenol becomes the majority in black olives ${ }^{15}$. Other natural phenols that have been identified in olive drupes are luteolin 7-glucoside, ligustroside, verbascoside, salidroside, rutin ${ }^{11}$. These compounds are also omnipresent in all parts of olive fruit, the major phenolic components in the seed are the hydroxytyrosol, oleuropein, salidroside, nuzhenide, nuzhenide 11-methyl oleosid, tyrosol, and demethyloleuropein ${ }^{16}$. In addition, the hydroxytyrosol and tyrosol participate in the structure of the stone ${ }^{17}$.

Various by-products of fruit and vegetable processing have been studied to find new sources of natural antioxidants. The purpose of this investigation was to study the influence of the enrichment of olive oil on of their quality during storage time using olive stones of Picholine variety as a source of natural polyphenolic antioxidants. For two reasons, the first is to maintain the quality of this unstable oil and therefore extend the storage time. The second is to enrich this food with compounds that are not foreign to the range of compounds naturally present in oils, in order to improve their nutritional and organoleptic qualities and not to modify them. In this sense, oils enriched with olive stone extracts were evaluated in terms of acidity, peroxide, and their absorption coefficients K270 and K232 during nine months of storage in the dark at room temperature.

\section{MATERIALS AND METHODS}

\section{Samples preparation}

The oils of the Arbequina variety subject of this study are collected from two different areas of the Beni MellalKhenifra region, sample (1) from Krifate area (E1) and sample (2) from Bukarone area (E2).

The extracts are obtained from five categories of olive stones:

$>$ Olive stones without seeds (SOWS), a by-product of the olive oil extraction unit obtained by filtering solid waste.

$>$ Whole olive stones, by-products of various processes for the preparation of table olives:

- Whole green olive stones with Spanish method (GOSNaOH).

- Green olive stones according to the traditional Moroccan $\mathrm{NaCl}$ (GOSNaCl) method.

- Black olive stones according to the Greek method (BOSNaOH).

- $\quad$ Black olive stones treated with dry salt (BOSNaCl).

The samples were separated from the pulp after two months of storage with an industrial pitting machine, with a $6 \mathrm{~mm}$ screen separator, which is the standard size in this industrial process. All samples were washed to remove any adhering flesh and dried for 48 hours at room temperature.

For the preparation of the extracts a quantity of olive stones powder was extracted using the method of maceration with a liquid solid ratio $(1 / 2)$ of ethanol $80 \%$ $(\mathrm{ETOH})$ for $76 \mathrm{~h}$ at room temperature. After the maceration, the extracts were filtered. The filtrate was evaporated under reduced pressure in a rotary evaporator at $35 \circ \mathrm{C}$ until the extracts became completely dry, and stored at $4^{\circ} \mathrm{C}$ until use.

\section{Analytical methods}

\section{Analysis of the extracts}

\section{$>$ Determination of total phenol}

The amount of total phenolic compounds in the extract was determined colorimetrically with the Folin-Ciocalteu (FC) reagent ${ }^{18}$. The reaction mixture contained $100 \mu \mathrm{l}$ of extract, $0.5 \mathrm{ml}$ of FC reagent and $2 \mathrm{ml}$ of sodium carbonate solution and was kept in the dark under ambient conditions for $30 \mathrm{~min}$ to complete the reaction. The absorbance of the resulting solution was measured at 760 $\mathrm{nm}$ in a spectrophotometer. The concentration of total phenolic compounds was calculated as gallic acid $(\mathrm{mg} / \mathrm{g}$ ) equivalent (GAE) from the calibration curve. All measurements were carried out in three replicates. 


\section{$>$ Determination of total flavonoid}

Total flavonoid contents (TF) of the stones extracts were determined according to the colorimetric assay ${ }^{18}$. One $\mathrm{ml}$ of properly diluted stones extract was mixed with $4 \mathrm{ml}$ of distilled water. At zero time, $0.3 \mathrm{ml}$ of $(5 \%, w / v)$ NaNO2 was added. After $5 \mathrm{~min}, 0.3 \mathrm{ml}$ of $(10 \%, \mathrm{w} / \mathrm{v}) \mathrm{AlCl} 3$ was added. At $6 \mathrm{~min}, 2 \mathrm{ml}$ of $1 \mathrm{M}$ solution of $\mathrm{NaOH}$ were added. Finally, the volume was made up to $10 \mathrm{ml}$, immediately by the addition of $2.4 \mathrm{ml}$ of distilled water. The mixture was shaken vigorously and the absorbance was read at $510 \mathrm{~nm}$. The flavonoids content was calculated as quercetin (mg equivalent (QE)/g DW).

\section{$>$ Determination of DPPH' radical scavenging activity}

DPPH was used to evaluate the radical scavenging activity (RSA) of the phenolic extracts. An amount of $2.95 \mathrm{~mL}$ of a $0.1 \mathrm{mM}$ methanolic DPPH solution was mixed in a cuvette with $50 \mu$ l of extract. The percentage of inhibition of DPPH was determined by measuring the decrease in the absorption of the mixture at $517 \mathrm{~nm}$ at intervals of $15 \mathrm{~s}$ during 5 min using the equation percentage of inhibition)

$$
\% \text { inhibition }=(A 0-A 1) / A 0 \times 100^{19}
$$

The results were expressed in milligrams of Trolox equivalents per $100 \mathrm{~g}$ initial dry matter using the equation obtained from the calibration curve of the reference compound.

\section{$>$ Determination of $\mathrm{ABTS}^{+}$radical scavenging activity}

$\mathrm{ABTS}^{+}$radical cation scavenging for the determination of the antiradical activity ${ }^{20}$, a protocol based on the ABTS ${ }^{+}$ free radical decolorization assay was used In brief; $5 \mathrm{ml}$ of a $7 \mathrm{mM} \mathrm{ABTS}$ solution was treated overnight in the dark with $88 \mu \mathrm{l}$ of a $140 \mathrm{mM}$ potassium persulfate solution to yield the $\mathrm{ABTS}^{+}$radical cation. Prior to use in the assay, the $\mathrm{ABTS}^{+}$radical cation was diluted with ethanol to an initial absorbance of about 0.700 (ratio of 1:88) at $734 \mathrm{~nm}$. Free radical scavenging activity was assessed by mixing $1.0 \mathrm{ml}$ of diluted $\mathrm{ABTS}^{+}$radical cation with $10 \mu \mathrm{l}$ of sample and the optical density (OD) of the solution was measured at 734 $\mathrm{nm}$, after $5 \mathrm{~min}$. the $\% \mathrm{ABTS}^{+}$scavenging activity = Abs (control) - Abs (sample) / x 100.

ABTS values are expressed as trolox mg equivalent/100g DW (mg TE/100g DW).

\section{Analysis of the olive oil}

The acidity is expressed as a percentage of oleic acid from olive oil. This is used as a simple and effective way for qualitative assessment and classification by commercial category of olive oil. Free acidity was given as percentage of oleic acid and determined by titration with $0.1 \mathrm{~N} \mathrm{KOH}$ of an oil solution in a previously neutralized solvent (ethanol/ethyl ether, 1:1) and using phenolphthalein as indicator. Peroxide value was expressed as milliequivalents of active oxygen per kilogram of oil (Meq $02 / \mathrm{kg}$ ) and determined by a mixture of oil, chloroform, and acetic acid left to react with potassium iodide in darkness. Free iodine was then titrated with a $0.01 \mathrm{~N}$ sodium thiosulfate solution. The specific extinction coefficients K232 and K270 were measured from the absorption in cyclohexane solution at 232 and $270 \mathrm{~nm}$ respectively ${ }^{21}$.

\section{RESULTS AND DISCUSSION}

\section{Phenol and flavonoid content and antioxidant activity of olive stones extract}

The results of phenolic contents (Table 1) show a considerable differences between stone categories that have undergone different treatments during the olive conservation process, its ranging from $184.62 \pm 5.72$ to $262.56 \pm 4.83 \mathrm{mg} \mathrm{AGE} / \mathrm{g}$ we observe in $\mathrm{BOSNaCl}$ the highest value of phenolic compound contents $(262.56 \pm 4.83 \mathrm{mg}$ AGE /g EX.) followed by BOSNaOH $(251,13 \pm 3.18 \mathrm{mg} \mathrm{AGE}$ /g EX), GOSNaCl (237.34 $\pm 6.61 \mathrm{mg} \mathrm{AGE} \mathrm{/g} \mathrm{EX)} \mathrm{and}$ GOSNaOH (184.62 $\pm 5.72 \mathrm{mg} \mathrm{AGE} \mathrm{/g} \mathrm{EX).} \mathrm{While} \mathrm{for} \mathrm{seedless}$ stone, the concentration of phenols is $245.75 \pm 4.49 \mathrm{mg} \mathrm{AGE}$ /g EX.

Table 1: Total phenol and flavonoid content and antioxidant activity of olive stones extract

\begin{tabular}{|l|c|c|c|c|}
\hline & $\begin{array}{c}\text { TP } \\
\text { (mg AGE/g EX) }\end{array}$ & $\begin{array}{c}\text { Flavonoid } \\
\text { (mg QE/g EX) }\end{array}$ & $\begin{array}{c}\text { DPPH } \\
\text { (mg TE/g EX) }\end{array}$ & $\begin{array}{c}\text { ABTS } \\
\text { (mg TE/g EX) }\end{array}$ \\
\hline BOSNaCl & $262.56 \pm 4.83$ & $123.42 \pm 2.72$ & $193.66 \pm 8.34$ & $385.53 \pm 10.65$ \\
\hline BOSNaOH & $251.13 \pm 3.18$ & $120.33 \pm 6.51$ & $116.25 \pm 4.22$ & $250.81 \pm 12.53$ \\
\hline GOSNaCl & $237.34 \pm 6.61$ & $104.25 \pm 3.66$ & $138.14 \pm 5.17$ & $281.27 \pm 9.84$ \\
\hline GOSNaOH & $184.62 \pm 5.72$ & $86.79 \pm 4.48$ & $96.32 \pm 9.61$ & $196.84 \pm 11.27$ \\
\hline OSWS & $245.75 \pm 4.49$ & $113.64 \pm 5.63$ & $231.82 \pm 6.72$ & $415.73 \pm 10.46$ \\
\hline
\end{tabular}

The flavonoid content ranges from $86.79 \pm .48$ to $123.42 \pm 2.72 \mathrm{mg} \mathrm{QE} / \mathrm{g} \mathrm{EX}$. the extracts of $\mathrm{BOSNaCl}$ and $\mathrm{BOSNaOH}$ also contain the highest concentrations of $123.42 \pm 2.72 \mathrm{mg} \mathrm{EQ} / \mathrm{g}$ EX and 120.33 $\pm 6.5 \mathrm{mg} \mathrm{EQ} / \mathrm{g} \mathrm{EX}$ respectively, followed by seedless stone with $113.64 \pm 5.63$ mg EQ/g EX. While GOSNaOH contains the low concentration $86.79 \pm 4.48 \mathrm{mg} \mathrm{EQ} / \mathrm{g}$.

In order to obtain more reliable results, antioxidant activity is evaluated by two different methods DPPH and ABTS. In the DPPH assay, all samples have significant antioxidant activity, the highest value is found on the seedless stone is in the order of $231.82 \pm 6.72 \mathrm{mg} \mathrm{TE} / \mathrm{g}$ EX followed by 
$\mathrm{BOSNaCl}$ and $\mathrm{GOSNaCl} 193.66 \pm 8.34 \mathrm{mg} \mathrm{TE} / \mathrm{g}$ EX and $138.14 \pm 5.17 \mathrm{mg} \mathrm{TE} / \mathrm{g} E X$, while the low activity is indicated on $\mathrm{BOSNaOH}$ and $\mathrm{GOSNaOH}$. For the second method based on the ABTS test, the values range from 196, 84 to 415.73 $\mathrm{mg} \mathrm{TE} / \mathrm{g}$ EX. The high value is always recorded in the stone without seed, followed by $\mathrm{BOSNaCl}$ and $\mathrm{GOSNaCl}$. Analysis of the results indicates that seedless stone extracts have a low total phenol content but high total antioxidant activity, this observation is due to the presence of some compounds characterized by higher antioxidant activity than compounds existing in the seed, such as compounds containing a tyrosol unit such as nüzhenide, compounds with this type of phenolic structure contribute less to the total phenolic content measured with the Folin reagent ${ }^{16}$. In addition, the other categories of olive stones also have high antioxidant activity, even if they are strongly affected by the conservation process, in particular, olive stones resulting from a conservation process based on an alkaline treatment have suffered high losses in antioxidant activity. It is important to note that the antioxidant activity of the stones is not corollary to the phenolic content but it is directly related to the nature of the phenols and their structures. Generally, olive stones have retained the majority of their $C P$ and $A A$ due to the cellulosic nature of the stones which protects the inner layers.

\section{Effect of enrichment on the oil stability}

The oils of the Arbequina variety have been enriched with the extracts obtained from olive stones of the Moroccan Picholine variety. The amount of added extract has been calculated to correspond to a polyphenol content of about $400 \mathrm{mg}$ per kg of oil, which is twice the limit proposed by the Joint FAO/WHO Expert Committee on Food Additives for a given synthetic antioxidant in fats and oils ${ }^{22,13}$.

\section{Evolution of the acidity index during storage}

The acidity of the oil is assessed by the amount of free fatty acids, expressed in grams of oleic acid per $100 \mathrm{~g}$ of oil. It has emerged as a simple and effective means of quantitative evaluation and commercial classification of olive oil [IOC2009].

During storage, the oil acidity increases due to the release of fatty acids by hydrolysis of triglycerides. For our study the lowest initial acidity is detected in Picholine oil in both regions (krifat E1: $0.208 \%$, Boukaroune E2: $0.321 \%$ ) followed by Arbequina oil with the following values (Krifat: $0.223 \%$ Boukaroune: $0.363 \%$ ) These results are of the same order as those reported by other authors ${ }^{23}$. The differences of the free acidity of the samples analyzed can be attributed to the factor related to olive varieties and technological practices in the grinding process. The evolution of the acidity of the enriched oil samples during the nine months of storage shows that the acidity of all samples was increased during the storage period (Figure 1 and 2).

Indeed, the acidity of the oils enriched with the deferent extracts underwent a similar increase in samples E1 and E2 with a slight difference. The Enriched samples show the low acidity values compared to controls (E1 and E2); this remark can be explained by a hydrolysis that contributes to the release of mono-acid or by the action of lipases ${ }^{24,25}$.

\section{Evolution of the peroxide value during storage}

The second criterion for quality assessment is the peroxide value. This index is used to assess the oxidation state of the oil during storage which should not exceed $20 \mathrm{Meq}\left(\mathrm{O}_{2}\right) / \mathrm{kg}$ for all categories of olive oil according to IOC (2009). The initial peroxide values of Picholine oils in E1 and E2 are respectively $5.13 \pm 0.21 \mathrm{Meq}\left(\mathrm{O}_{2}\right) / \mathrm{Kg}$ and $5.73 \pm 0.18 \mathrm{Meq}$ $\left(\mathrm{O}_{2}\right) / \mathrm{Kg}$ they are lower than those observed in Arbequina oil in samples E1 and E2 respectively $5.32 \pm 0.22 \mathrm{Meq}\left(\mathrm{O}_{2}\right) / \mathrm{kg}$ and $5.96 \pm 0.13 \mathrm{Meq}\left(\mathrm{O}_{2}\right) / \mathrm{kg}$. The variations observed can be due to the difference in the degree of maturity of the olives but also depend on the variety cultivated and the geographical area ${ }^{26}$.

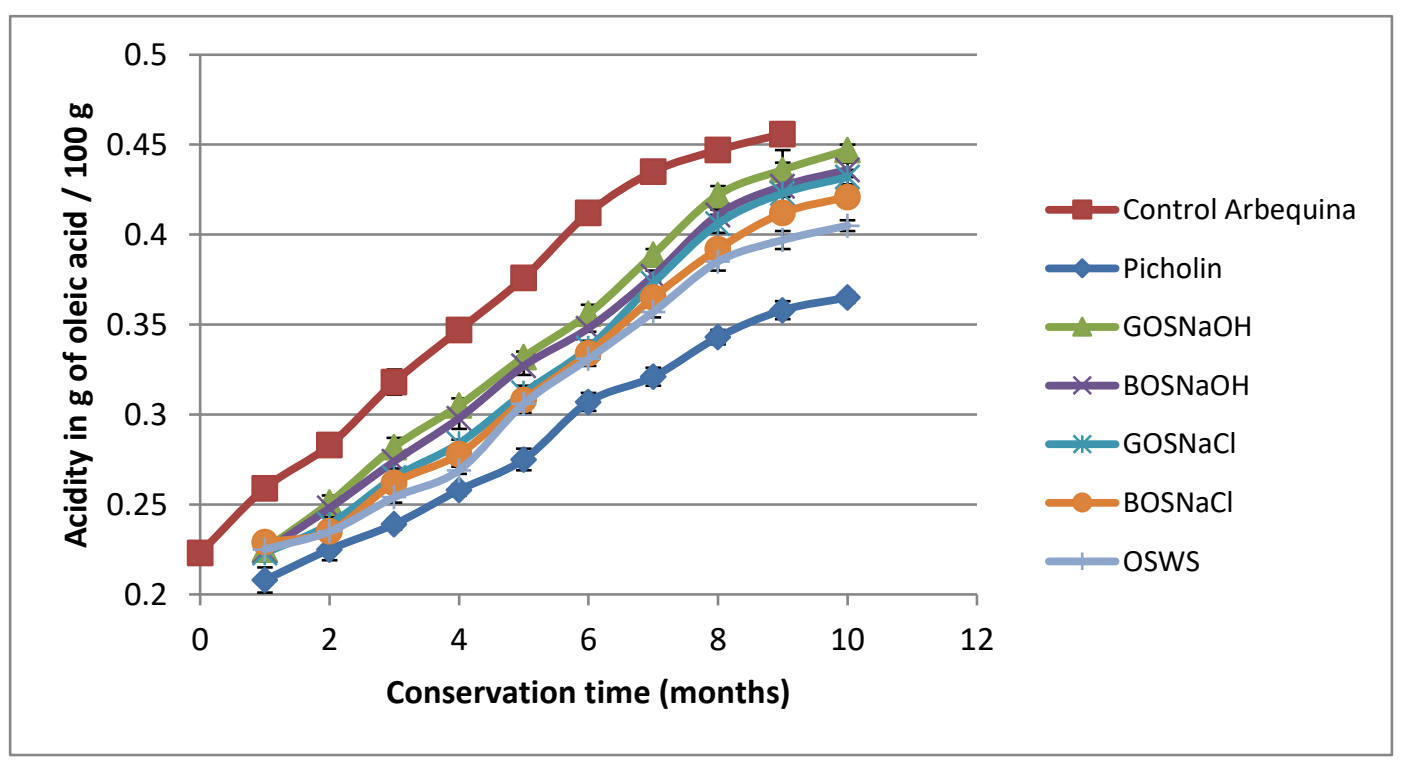

Figure 1: Evolution of the acidity of olive oil enriched with extracts of OSWS, WBOSNaCl, WGOSNaCl, WBOSNaOH and WGOSNaOH, from Krifate area in Morocco E1. 


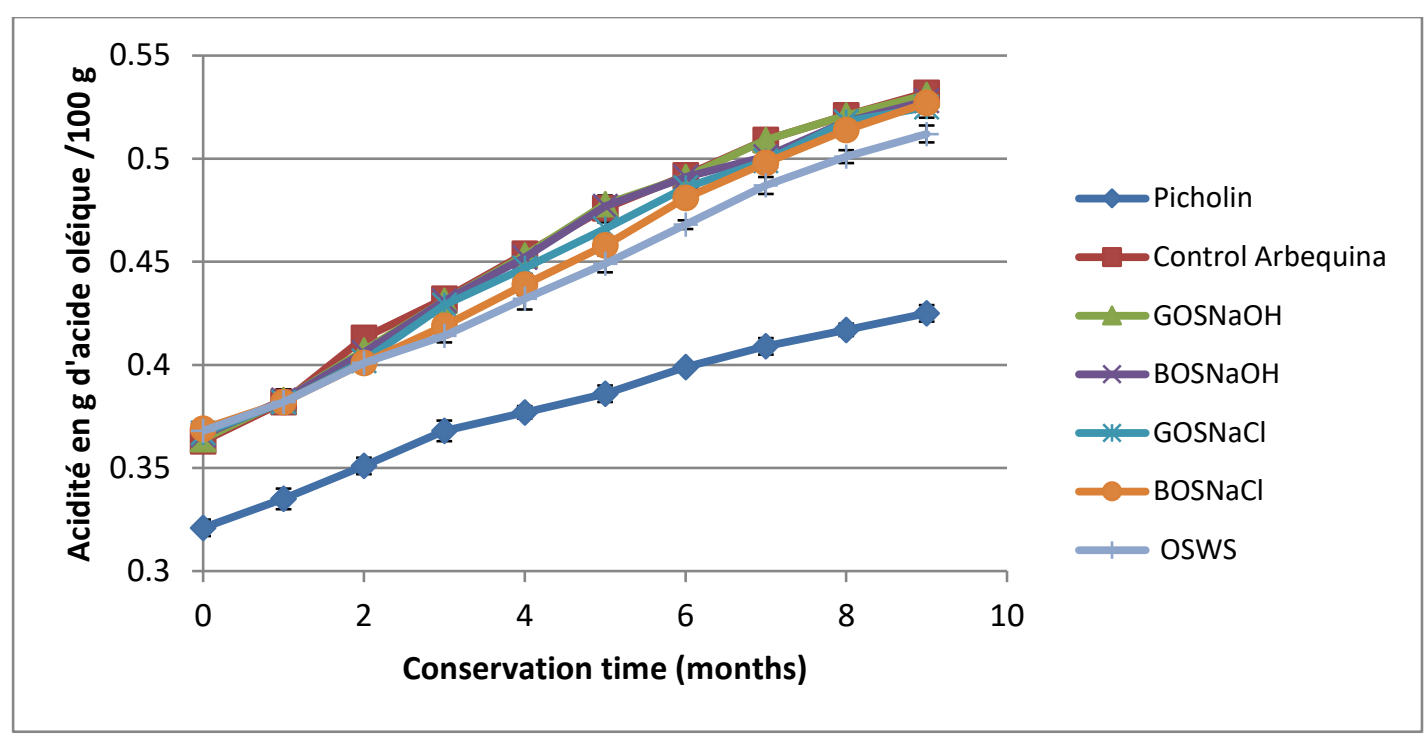

Figure 2: Evolution of the acidity of olive oil enriched with extracts of OSWS, WBOSNaCl, WGOSNaCl, WBOSNaOH and WGOSNaOH, from Boukaroune area in Morocco E2.

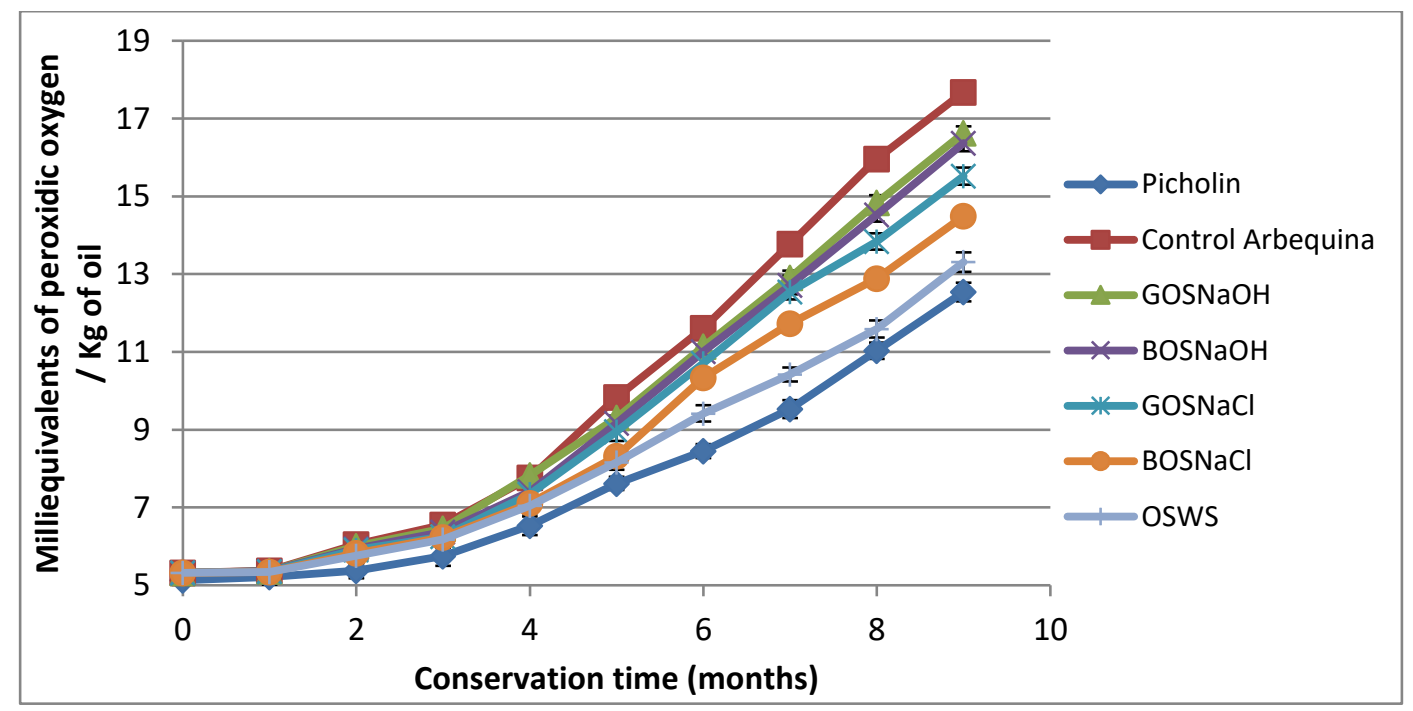

Figure 3: Evolution of the peroxide value of olive oil enriched with extracts of OSWS, WBOSNaCl, WGOSNaCl, WBOSNaOH and WGOSNaOH, from Krifate area in Morocco E1.

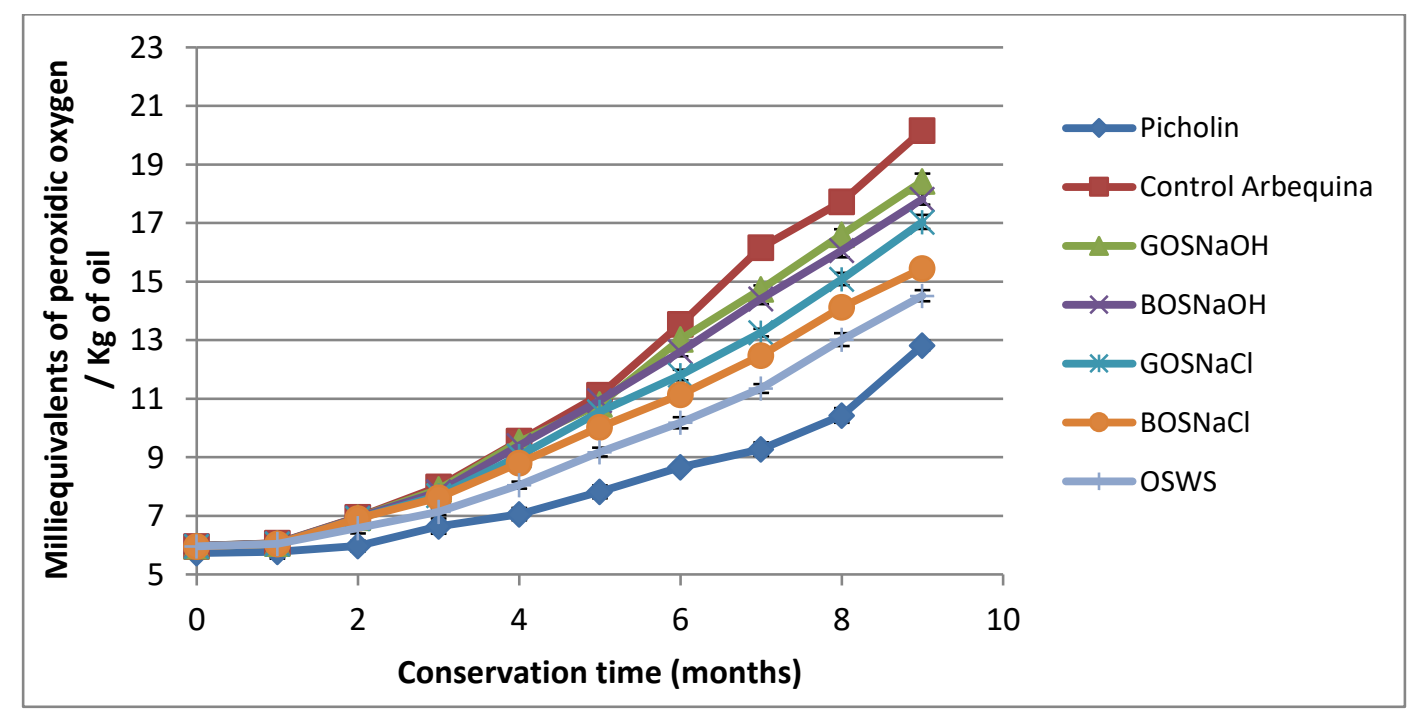

Figure 4: Evolution of the peroxide value of olive oil enriched with extracts of OSWS, WBOSNaCl, WGOSNaCl, WBOSNaOH and WGOSNaOH, from Boukaroune area in Morocco E2. 
The Results (figures 3 and 4) show that all oils have also undergone an evolution of the peroxide value during the storage period, this evolution is very pronounced in the Arbequina oil with values ranging from 5.32 to $17.68 \mathrm{Meq}$ $\left(\mathrm{O}_{2}\right) / \mathrm{kg}$ in $\mathrm{E} 1$ and 5.96 to $20.16 \mathrm{Meq}\left(\mathrm{O}_{2}\right) / \mathrm{kg}$ in E2. On the other hand, the samples of Moroccan Picholine were appear more stable with values ranging from 5.13 to 12.54 Meq $\left(\mathrm{O}_{2}\right) / \mathrm{kg}$ in E1 and from 5.73 to $12.82 \mathrm{Meq}\left(\mathrm{O}_{2}\right) / \mathrm{kg}$ in E2. The Arbequina oil from E2 reaches a value of $20.16 \pm 0.17$ Meq $\left(\mathrm{O}_{2}\right) / \mathrm{kg}$ after nine months of storage in the dark under ambient conditions consequently it loses their extra virgin quality (the limit standard is $20 \mathrm{Meq}\left(\mathrm{O}_{2}\right) / \mathrm{kg}$.

These results are consistent with those of ${ }^{27,7}$ who provided values ranging from $19.35 \mathrm{Meq}\left(\mathrm{O}_{2}\right) / \mathrm{kg}$, to $20.41 \mathrm{Meq}$ $\left(\mathrm{O}_{2}\right) / \mathrm{kg}$ after 12 months of storage under same conditions. Concerning enriched oils with extracts of $\mathrm{BOSNaCl}$, GOSNaCl, BOSNaOH, GOSNOH show less intense oxidation respectively in the aforesaid order compared to that of the Arbequina control oils in both areas of culture E1, E2 the peroxide values ranging from 14.49 to $16.68 \mathrm{Meq}\left(\mathrm{O}_{2}\right) / \mathrm{kg}$ in samples enriched with different extracts opposite of 17.68 in Arbequina control E1, and 15.45 to $18.43 \mathrm{Meq}\left(\mathrm{O}_{2}\right) / \mathrm{kg}$ in samples enriched, opposite of $20.16 \mathrm{Meq}\left(\mathrm{O}_{2}\right) / \mathrm{kg}$ observed in Arbequina control E2 which loses its extra virgin quality after nine months of storage.

Furthermore, the results observed in the oils enriched with extract of seedless olive stone are shown a high resistance to the oxidation assimilated to that of the variety Picholine source of the extracts. The peroxide values are $13.31 \pm 0.25$ Meq $\left(\mathrm{O}_{2}\right) / \mathrm{kg} 14.52 \pm 0.19 \mathrm{Meq}\left(\mathrm{O}_{2}\right) / \mathrm{kg}$ respectively in $\mathrm{E} 1$ and E2. Therefore, enriched oils with SOWS retained its extra virgin quality in both samples. The observed differences in peroxide values reflecting the resistance of oils to oxidation are influenced by the nature of the phenolic compounds contained in extracts prepared from green and black olive stones, which have different contents of certain types of phenols. For example, the oleuropein and hydroxytyrosol, its concentration depends in with fruit maturation ${ }^{15}$ these compounds considered to confer a high protection against autoxidation and thermo-oxidation of olive oil ${ }^{28}$.

General phenolic compounds considered to be natural antioxidants that protect the oil from oxidation and give it the stability during storage ${ }^{29}$. Olive stones also contain three glucosides including salidroside (tirosol-glucose), nuzhenide (glucose-elenolic acid-glucose-tyrosol) and nuzhenide-oleoside, and two secoroiridoid glucosides with tirosol, elenolic acid and glucose fractions with sequence differences were isolated from olive stone ${ }^{30}$. Nuzhenide is present only in the stone, as the predominant phenol, and the verbascoside appears in significant amounts only in the seed and pulp ${ }^{31}$.

The high content of phenolic compounds in the stone allows decreasing the oxidation phenomenon in enriched oils.

\section{Evolution of the specific extinctions of olive oil during storage}

Measuring the peroxide value is verified by the determination of UV absorbance at $232 \mathrm{~nm}$ and $270 \mathrm{~nm}$. K232 is useful for evaluate the formation of primary oxidation products, Linolenic hydroperoxides and oxidized fatty acids that are dienes resulting from the decomposition ${ }^{32}$. The secondary oxidation products hydroperoxides especially diketones and unsaturated ketones absorb light near to 270nm (E270) ${ }^{33}$.

The E270 and E232 coefficients evolve regularly during the 9 months of storage (Figures 5 and 6) and follow the same trend as the evolution of the peroxide value, after an initiation phase the coefficients change rapidly during storage time. The pent variations observed on the graphs due to the accumulation of oxidation compounds and their degradation during storage time. It should be noted that absorbance exceeds the limit standard [IOC 2009] in samples with peroxide values exceeding $20 \mathrm{Meq}\left(\mathrm{O}_{2}\right) / \mathrm{kg}$.

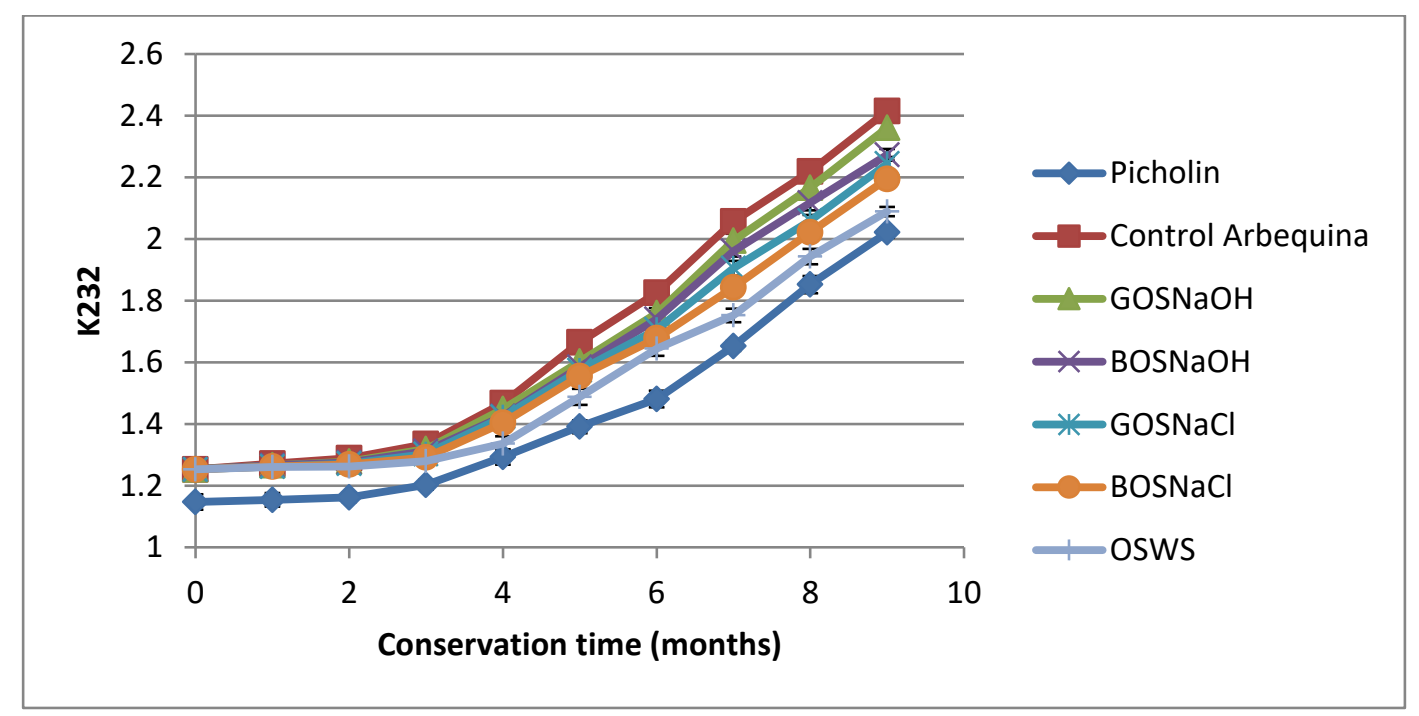

Figure 5: Evolution of the extinction coefficients at $232 \mathrm{~nm}$ of olive oil enriched with extracts of OSWS, WBOSNaCl, WGOSNaCl, WBOSNaOH and WGOSNaOH, from Krifate area in Morocco E1. 


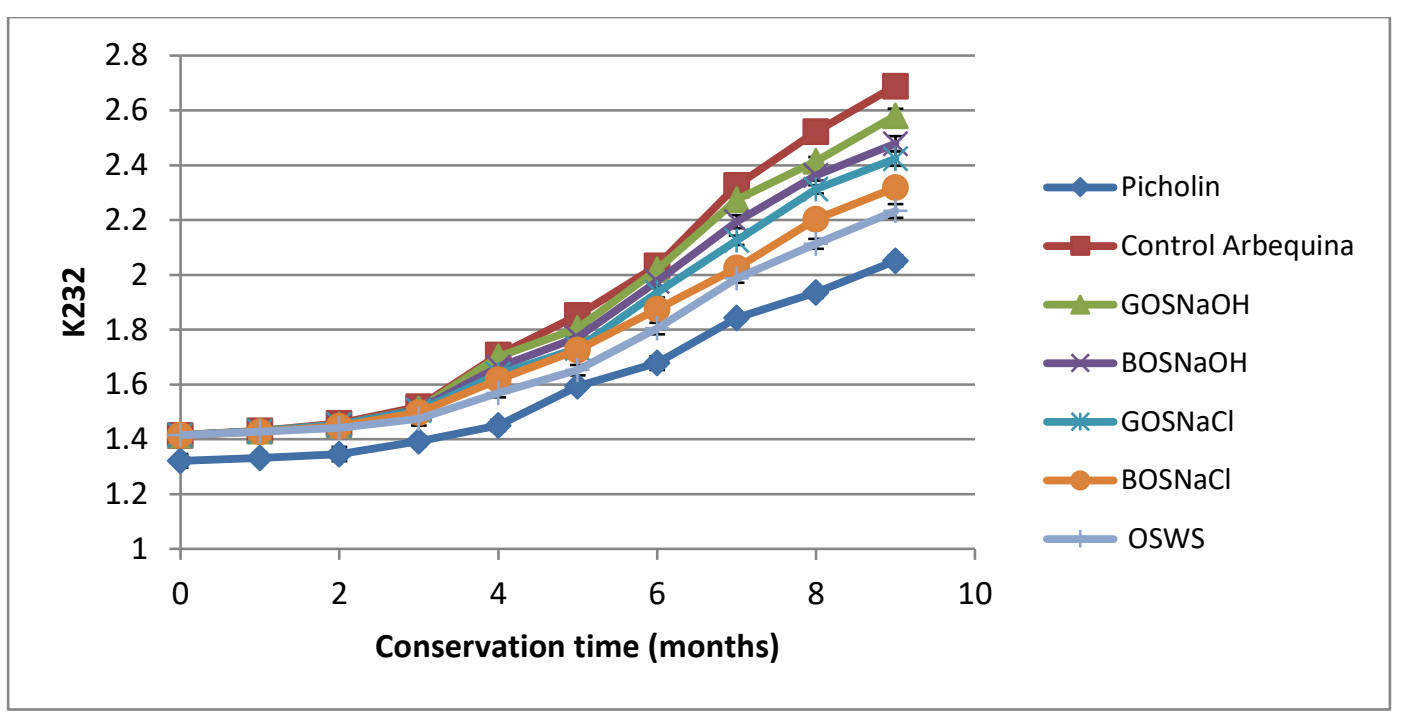

Figure 6: Evolution of the extinction coefficients at $232 \mathrm{~nm}$ of olive oil enriched with extracts of OSWS, WBOSNaCl, WGOSNaCl, WBOSNaOH and WGOSNaOH, from Boukaroune area in Morocco E2.

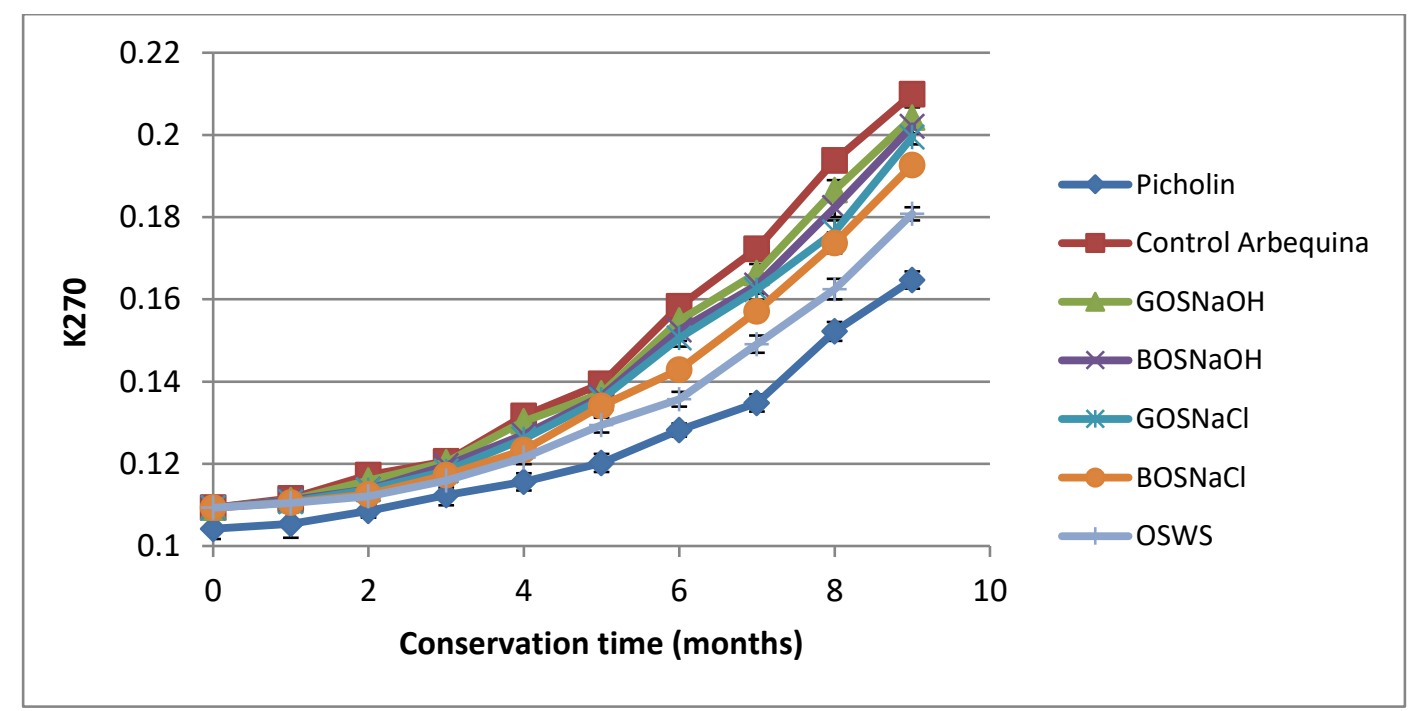

Figure 7: Evolution of the extinction coefficients at $270 \mathrm{~nm}$ of olive oil enriched with extracts of OSWS, WBOSNaCl, WGOSNaCl, WBOSNaOH and WGOSNaOH, from Krifate area in Morocco E1.

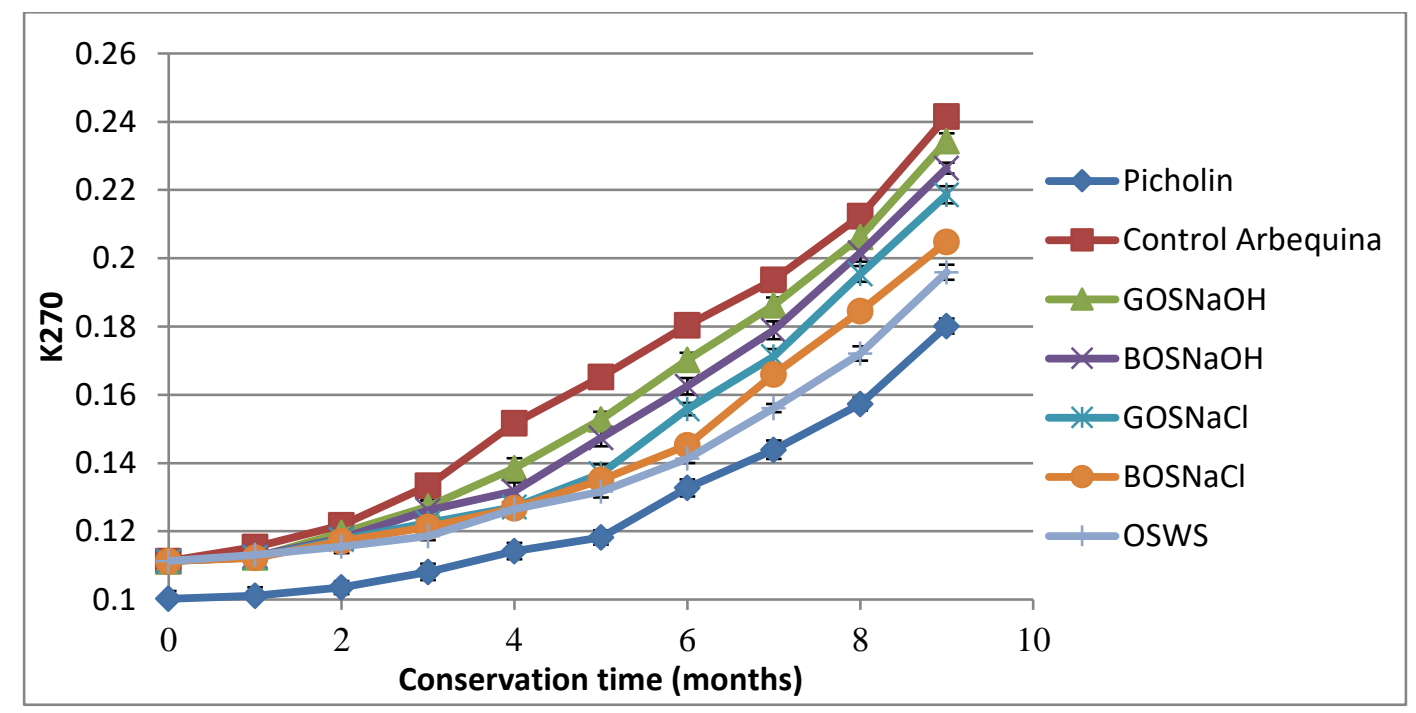

Figure 8: Evolution of the extinction coefficients at $270 \mathrm{~nm}$ of olive oil enriched with extracts of OSWS, WBOSNaCl, WGOSNaCl, WBOSNaOH and WGOSNaOH, from Boukaroune area in Morocco E2. 
In addition, the samples enriched with extracts from the seedless stones showed the lowest values when measuring the two coefficients E270 and E232. The values recorded are respectively, in the first zone E1 (E232: 2.089 \pm 0.015 . E270: $0.1808 \pm 0.0016)$ against (E232: $2.415 \pm 0.017$. E270: $0.2099 \pm 0.0022$ ) observed in the control sample. In the second zone E2 the coefficients follow the same evolution (E232: 2.233 \pm 0.025 . E270: $0.1959 \pm 0.0022$ ) opposite to (E232: 2.689 \pm 0.023 . E270: $0.2415 \pm 0.0024$ ) in the control sample. These results confirm that the enriched samples have acquired a resistance to oxidation in compared to the controls.

The specific extinction at $232 \mathrm{~nm}$ and $270 \mathrm{~nm}$ of oil reflects its oxidation state. The stronger its extinction at $232 \mathrm{~nm}$, the more peroxidized it is Similarly, the higher the extinction at $270 \mathrm{~nm}$, the richer the oil is in secondary oxidation products and reflects its low storability ${ }^{34,25}$. As for the variation in specific extinction, it varies from one sample to another, but its value remains comparable to that established by the International Olive Council ${ }^{21}$.

The observed differences in peroxide indices and the two coefficients in oils enriched by OSWS extracts and oils enriched by extracts containing the seeds (WBOSNaCl, WGOSNaCl, WGOSNaCl, WBOSNaCl, WBOSNaCl, WGOSNaCl), explained by the enzymatic oxidation intervention, This type of oxidation catalyzed by highly concentrated enzymes in the olive seed, This hypothesis has been confirmed by ${ }^{35}$ who have shown that the destining process excluding the olive seed, partially eliminates the peroxidase activity in pasta and can therefore reduce the enzymatic degradation of hydrophilic phenols in oils during the process improving their oxidative stability and organoleptic properties.

\section{CONCLUSION}

The results of our study show that the oil of the Arbequina variety is less stable in terms of oxidation compared to the oils of the Moroccan Picholine variety.

Enrichment with olive stones extracts partially reduced acid hydrolysis and increased resistance to oxidation especially in oils enriched with seedless olive stones extracts.

Furthermore, the results show that the stone extracts prolong the storage times of olive oil. These extract exhibit excellent antioxidant activity and can be used as alternative to synthetic antioxidants in foods that contain an oily fraction or as a natural source of antioxidants for active foods.

\section{REFERENCES}

1. Iqbal S, \& Bhanger MI. Stabilization of sunflower oil by garlic extract during accelerated storage. Food Chemistry 2007;100(1):246-254.

2. Development Branch production chains, Ministry of Agriculture and Maritime Fishing, Rabat, Morocco 2013.

3. Pinatel C, Petit C, Ollivier D, \& Artaud J. Outils pour I'amélioration organoleptique des huiles d'olive vierges. Oléagineux corps gras lipides 2004;11(3):217-222.

4. Tsimidou MZ, Georgiou A., Koidis A., \& Boskou D. Loss of stability of "veiled" (cloudy) virgin olive oils in storage. Food Chemistry 2005;93(3):377-383.

5. Criado MN, Morelló JR, Motilva MJ, \& Romero MP. Effect of growing area on pigment and phenolic fractions of virgin olive oils of the Arbequina variety in Spain. Journal of the American Oil Chemists' Society 2004;81(7):633.

6. Rahmani M, Mediterranean Olive Tree Days 2008, octobre, Meknes, Morocco.

7. Essiari M, Mouhajir A, El Hayani SM, El Kahkahi R, Lemrhari A, Errakhi R, \& Bachir S. Evaluation of the physicochemical quality parameters of virgin olive oils from four varieties Moroccan (Moroccan Picholine, Arbequina, Haouzia and Menara) during storage. International Journal of Food Science and Nutrition Engineering 2015;5:154-162.

8. Prior RL. Absorption and metabolism of anthocyanins: potential health effects. Phytochemicals: Mechanisms of action 2004;1-19.

9. Servili M, \& Montedoro G. Contribution of phenolic compounds to virgin olive oil quality. European Journal of Lipid Science and Technology 2002;104(9-10):602-613.

10. Antolovich M, Prenzler P, Robards K, \& Ryan D. Sample preparation in the determination of phenolic compounds in fruits. Analyst 2000;125(5):989-1009.

11. Ryan D, Antolovich M, Herlt T, Prenzler PD, Lavee S, \& Robards K. Identification of phenolic compounds in tissues of the novel olive cultivar hardy's mammoth. Journal of agricultural and food chemistry 200;250(23):6716-6724.

12. Visioli F, \& Galli C. Biological properties of olive oil phytochemicals. Critical reviews in food science and nutrition 2002;42(3): 209-221.

13. Farag RS, El-Baroty GS, \& Basuny AM. The influence of phenolic extracts obtained from the olive plant (cvs. Picual and Kronakii), on the stability of sunflower oil. International journal of food science \& technology 2003;38(1):81-87.

14. Amiot MJ, Fleuriet A, \& Macheix JJ. Importance and evolution of phenolic compounds in olive during growth and maturation. Journal of Agricultural and Food Chemistry 1986;34(5):823-826.

15. Romero C, Brenes M, García P, \& Garrido A. Hydroxytyrosol 4- $\beta$-D-glucoside, an important phenolic 
compound in olive fruits and derived products. Journal of Agricultural and Food Chemistry 2002;50(13):3835-3839.

16. Silva S, Gomes L, Leitão F, Bronze M, Coelho AV, VillasBoas L. Secoiridoids in olive seed: characterization of nüzhenide and 11-methyl oleosides by liquid chromatography with diode array and mass spectrometry. Grasas y Aceites 2010;61(2):157-164

17. Fernández-Bolaños J, Felizón $B$, Brenes $M$, Guillén $R$, \& Heredia A. Hydroxytyrosol and tyrosol as the main compounds found in the phenolic fraction of steamexploded olive stones. Journal of the American Oil Chemists' Society 1998;75(11):1643-1649.

18. Bozin B, Mimica-Dukic N, Samojlik I, Goran A, \& Igic R. Phenolics as antioxidants in garlic (Allium sativum L., Alliaceae). Food chemistry 2008;111(4) :925-929.

19. Brand-Williams W, Cuvelier ME, \& Berset CLWT. Use of a free radical method to evaluate antioxidant activity. LWTFood science and Technology 1995;28(1):25-30.

20. Otunola GA, Afolayan AJ. Evaluation of the polyphenolic contents and some antioxidant properties of aqueous extracts of Garlic, Ginger, Cayenne Pepper and their mixture. Journal of Applied Botany and Food Quality 2013;86:66-70.

21. International Olive Oil Council (2013) Trade standard applying to olive oil and olive pomace oil. In: (RES. COI/T.15/NC no. 3/Revision 7).

22. JECFA, Joint FAO/WHO Expert Committee on Food Additives (2005). General Standard for Food Additives. Codex Alimentarius Commission Standard Document CAC/STAN 192-1995, Rev. 6.

23. Dabbou S, Gharbi I, Brahmi F, Nakbi A, \& Hammami M. Impact of packaging material and storage time on olive oil quality. African Journal of Biotechnology 2011;10(74):16929-16936.

24. El Antari A, Hilal A, Boulouha B, \& El Moudni A. Influence of variety, environmental and cultural techniques on the characteristics of olive fruits and the chemical composition of extra virgin olive oil in Morocco. Olivae 2000;80:29-36.

25. Boulfane S, Maata N, Anouar A, \& Hilali S. Caractérisation physicochimique des huiles d'olive produites dans les huileries traditionnelles de la région de la Chaouia-Maroc. Journal of Applied Biosciences 2015;87:8022-8029.

26. García A, Brenes M, García P, Romero C, \& Garrido A. Phenolic content of commercial olive oils. European Food Research and Technology 2003; 216(6):520-525.

27. Guil-Guerrero JL. Quality of extra virgin olive oil affected by several packaging variables. Grasas y Aceites 2009;60(2):125-133.

28. Vekiari SA, Papadopouloua $P$, and Koutsaftakisb A. Comparison of different olive oil extraction systems and the effect of storage conditions on the quality of the virgin olive oil. Grasas y Aceites 2002;53:324-329.

29. Tanouti K, Serghini-Caid H, Chaieb E, Benali A, Harkous M, \& Elamrani A. Amélioration qualitative d'huiles d'olive produites dans le Maroc oriental. Les technologies de laboratoire 2011;6(22).

30. Maestro-Duran R, Cabello RL, Ruiz-Gutierrez V, Fiestas $P, \&$ Vazquez-Roncero A. Bitter phenolic glucosides from seeds of olive (Olea europaea). Grasas y Aceites 1994;45(5):332-335.

31. Ryan D, Prenzler PD, Lavee S, Antolovich M, \& Robards K. Quantitative changes in phenolic content during physiological development of the olive (Olea europaea) cultivar Hardy's Mammoth. Journal of Agricultural and Food Chemistry 2003;51(9):2532-2538.

32. Gharby S, Harhar H, Kartah B, Chafchauni I, Sibawayh Z, \& Charrouf Z. Chemical Characterization and oxidative stability of two monovarietal virgin olive oils (Moroccan Picholine and Arbequina) grown in Morocco. Journal of Materials and Environmental Science 2013;4(6) :935-942.

33. Harhar H, Gharby S, Kartah B, El Monfalout, H, Guillaume D, \& Charrouf $Z$. Influence of argan kernel roasting-time on virgin argan oil composition and oxidative stability. Plant Foods for Human Nutrition 2011;66(2):163168.

34. Wolff J-P. Manuel d'analyse des corps gras. 1968 Edition. Azoulay, Paris.

35. Restuccia D, Spizzirri UG, Chiricosta S, Puoci F, Altimari I, \& Picci N. Antioxidant properties of extra virgin olive oil from cerasuola cv olive fruit: effect of stone removal. Italian Journal of Food Science 2011;23(1):62-71.

Source of Support: The author(s) received no financial support for the research, authorship, and/or publication of this article.

Conflict of Interest: The author(s) declared no potential conflicts of interest with respect to the research, authorship, and/or publication of this article.

For any question relates to this article, please reach us at: editor@globalresearchonline.net New manuscripts for publication can be submitted at: submit@globalresearchonline.net and submit_ijpsrr@rediffmail.com 